\title{
A Particularly Tragic Case of Possible Alzheimer's Disease, that of Marshal Pétain
}

\author{
Jadwiga Attier-Zmudka ${ }^{1}$ and Jean-Marie Sérot ${ }^{1, *}$ \\ Department of Geriatrics, CH de Saint Quentin, Saint Quentin, France
}

Accepted 1 July 2019

\begin{abstract}
After World War I and more particularly in June 1940, the prestige of French Marshal Philippe Pétain, considered as the winning general the battle of Verdun, was very high. He became President of Council while the French army was unable to stop the German offensives. But five years later he was sentenced to death for high treason. By rereading his bibliography from a medical perspective, it is possible to find multiple suggestive events and to affirm a posteriori Pétain suffered from a neurodegenerative disorder, whose first signs appeared in the 1930s, suggestive of Alzheimer's disease, which had an impact on French politics. The modern medical knowledge of this disease casts a new light on the behavior of Petain during the last war.
\end{abstract}

Keywords: Alzheimer's disease, dementia, neurocognitive syndrome, Pétain

\section{INTRODUCTION}

Neurocognitive syndromes affect mostly elderly people; they can often alter family environment and sometimes have tragic consequences. The case of Philippe Pétain is particularly illustrative. He was made Marshal of France in 1918 after his decisive role in the Battle of Verdun. This prestigious title is purely honorary and a reward to French generals who led a victorious army. In June 1940, he was 84 years old; he enjoyed great prestige. The majority of the French population welcomed him as a savior, was very grateful to end the nightmare of this unimaginable defeat, and appreciated his spirit of sacrifice. Five years later he was sentenced to death for high treason; he was finally kept in jail where he died "completely senile" in 1951.

\footnotetext{
${ }^{1}$ These authors contributed equally to this work.

${ }^{*}$ Correspondence to: Prof Jean-Marie Serot, MD, PhD, 46 rue Lamartine, 80000 Amiens, France. Tel.: +33662276055; E-mail: jean-marie.serot@wanadoo.fr.
}

Before and during the Second World War, the term "senility" was part of the popular language, had a pejorative connotation, and was largely used by physicians to describe the set of cognitive and physical deterioration that occurs with aging. "Senility" was considered as a physiological condition and "dementia" as a natural consequence of aging [1]. But in 1976, following Katzman's works, Alzheimer's disease (AD) which was initially discovered in a 56-year-old woman, and "senile dementia" which presents the same anatomical lesions, were recognized to be one single disease [2]. Since then, Katzman's views had been controversial because of the now recognized heterogeneity. Other neurodegenerative illnesses were subsequently and progressively identified. This explains the ignorance of Pétain's pathological cognitive disorders by his contemporaries. Afterwards historians [3-10], who were not doctors, ignored Katzman's works and kept the term that was used in the medical documentation of the time; they did not make the connection between the numerous suspicious facts and a possible neurodegenerative pathology. Jennekens, in 2014, rereading 
from a medical perspective the many books that were available to him, diagnosed a predementia process at the beginning of the war [11]. These last years, new works were published $[8,9,12,13]$. It is possible to find multiple suggestive anecdotes and to affirm $a$ posteriori that Philippe Pétain suffered from a neurodegenerative disorder, beginning well before 1940, suggestive of AD, which had an impact on French politics.

\section{THE NEUROCOGNITIVE DISORDERS OF PHILIPPE PÉTAIN}

Pétain's decline was indirectly observed at multiple junctures in the last decade of his political career. As early as 1931, his collaborators reported that "he forgets and does not assimilate anymore" [4]. In 1934, while he was Minister of War, General Weygand, vice-president of the Superior Council of War, considered "he does not know his files and he is probably too old for his position as minister" [14]. In the same year he made retrograde remarks which did not consider the progress of armaments; for example, he thought it was useless to fortify the Ardennes that the Germans will never cross it, while it is precisely through this region they penetrated France [15]. In 1937, before the Swiss General Staff in Lausanne [8], and the following year in the preface of the book of General Chauvineau [16], he declared that tanks would be of little use in the event of a new war. In 1938, according to his copy writer, commandant Loustanau-Lacau, he often appeared absent and stayed for hours in front of his papers without reading them, "his mind is closed for old age" [6]. From 1939 until May 1940, he was the French ambassador to Spain, and with his staff, he negotiated the return of Spanish Republicans gold.

In May 1940, while the French Army retreated, the government recalled him in the hope that his presence will instill a renewed fighting spirit to the French army. All admired his exceptional physical condition; however, those close to him recognized that "sometimes the brain works badly" [15]. He was aware of this, so he refused the position of Minister of Foreign Affairs, "I can only deal with what I know, I cannot learn anymore" [17]. He was "apathetic" to the councils of ministers, the reciprocation of discussions escaped him, and some people called him "pasty" [5]. Sometimes he made totally inappropriate remarks; for example, he suggested the use of carrier pigeons to compensate for bad radio connections [18].
General Spears, sent by Winston Churchill, explained to him on June 6, that someone like Jeanne d'Arc would be needed to save France, he got a speech that he made in 1937 and read all of it; Spears thought he was "pitiful" [5]. On June 7, Paul Reynaud, the President of the Council (equivalent of Prime Minister), before the advance of the German armies considered the possibility of declaring Paris an "open city", and asked the ministers for their opinion; Pétain then said he was surprised by the appointment of Colonel Charles de Gaulle to a ministerial post and explained at length that this ungrateful man had dared to publish a book without his agreement, it was totally inappropriate given the seriousness of the situation [9]. On June 16, while the French army was totally defeated, he accepted the post of President of the Council and his representatives negotiated the armistice.

While forming his government, he offered Pierre Laval the ministry of Justice. Laval stated his preference for the post of minister of Foreign Affairs. Pétain accepted although he had already attributed the position to Paul Baudoin. When his entourage, particularly General Weygand, pointed out that this would complicate relationships with the British, Petain gave again the ministry of Justice to Laval who again declined the proposal [3].

On June 17, without any notification to the ministers, he made during a radio address the quite shocking statement "I give to France the gift of my person", but unfortunately he added "yet I feel my heart is aching, and I tell you, we must stop the fight"; while the discussions for the armistice would start only 48 hours later, the effect on the morale of troops was disastrous and many regiments refused to fight [15].

The same day, a collaborator informed him of "preparations for a rebellion against the government" from Georges Mandel who was minister of the Interior up until the day beforehand. Without investigation, he himself signed an arrest warrant to counter the latter. This arrest was rapidly known and Albert Lebrun, President of the Republic, made known his disapproval. Mandel was freed and went to Pétain's office immediately. Appalled, he asked for written apology, which Pétain provided without delay. Mandel found it insufficient and demanded a more explicit text and Pétain amended his previous text [15]. The first hours of the Presidency of the Council show how Pétain presented a lack of critical thinking and poor judgement. His personality had changed; formerly very authoritarian, he became hesitant and generally 
agreed with the last statement made in front of him [18].

On June 19, he did not recognize the Spanish Minister of Foreign Affairs, although he had seen him at least 10 times during his embassy in Madrid a few weeks earlier [19]. Some members of parliament, for example, Marcel Héraud, Georges Mandel, and Jacques Bardoux, knew his deficiencies and despite them, voted for full powers on July 10 [7, 20], and finally he was appointed Head of the French State, and as such officially led the country's politics.

Shortly after, a member of his entourage specified that "he is good 3-4 hours a day, especially in the morning when he is rested, but his collaborators can make him sign anything when he is tired" [21]; in other words, from the beginning of the war, it means he was the victim of abuse of weakness.

From 1941, the witnesses reported long hours of absence, generating "a situation that becomes tragic some days" [5]. The ambassadors of the United States [22] and Germany [7] knew of this cognitive deterioration and informed their respective governments.

From 1942, his speeches were sometimes confused, censored, and rewritten before publication in the press [8]. In April 1942, Laval, a pro-German politician, was appointed Head of Government whilst Pétain remained Head of State [4]. Pétain did not oppose the mass arrest of Jews at the Vélodrome d'Hiver (July 1942) [4], the forced incorporation of Alsatians and inhabitants of Lorraine within the Wehrmacht (August 1942) [4], and the establishment of mandatory labor service (STO, service du travail obligatoire) in Germany for young French people (September 1942) [8].

$\mathrm{He}$ also had episodes of confusion, for example in July 1942, when visiting a hospital in Lyon he asked the mayor of this city "who am I, where am I, what am I doing?" and the mayor answered, "you are Marshal Pétain and you are visiting the Hôpital de la Charité in Lyon" [23]. In October 1942, Laval judged that "this old man does not have his head and is good only to sign papers" [23].

After the Anglo-Americans landing in North-West Africa in November 1942, the Germans invaded the South of France, and he was unable to leave France and to go to Algeria despite the express requests of some of his collaborators. He was even confused and disoriented; Jean Jardel, his secretary general, stated "the marshal is no longer here" [5]. His doctor, Bernard Ménétrel, was finally obliged to prescribe him some rest for several days, and asked that he no longer be disturbed during the night [7]. From this day on, he did not attend Ministry Councils and the meeting dates were no longer communicated to him, which did not trouble him [5]. A few weeks later, in January 1943, he seemed very serene and made incoherent remarks about military operations in North Africa [24]. One day he had lunch and talked for a long time with a visitor; in the afternoon he met him again and asked that he be introduced to him once more as if he had never seen him [15].

In 1944, his wife reported nocturnal ambulations [13]. The Germans forced him to leave Vichy on the August 20, 1944 and deported him to Sigmaringen, from where he fled to Switzerland on April 23, 1945. He voluntarily surrendered to the French authorities in defense of his honor on April 26 and was immediately incarcerated [8]. During the preparation and the duration of his trial, in 1945, his wife agreed to be interned with him to help with his toileting and food [8]. His lawyers reported a lack of memory and confusion of events [6]; at their request, he refused to speak at his trial, officially because he held the High Court of Justice for illegal, and informally because "his mind becomes numb" [6], even though he appeared 20 years younger than he was [6].

After his internment on the island of Yeu, his cognitive functions declined rapidly: in 1945, he did not recognize his lawyers and his prison officer despite seeing him 10 times a day [25]. On 16 February 1947 he wrote to his spouse, the writing was regular, the letters were perfectly formed, there was no micrography [26]. The same year, before a parliamentary committee, he hardly remembered the war and the commission concluded that he was "senile" [27]. Despite this report, the French Republic kept this demented, dependent old man in detention, who had been nicknamed "the oldest prisoner in the world" [12]. The following months he presented compulsive activities, wanted to kiss the nuns, made obscene remarks, became incontinent; his hunter's step disappeared to give way to a hesitant step, and finally on July 23, 1951, he died of "senile decrepitude" [27]; no autopsy was performed [25].

\section{DISCUSSION}

During physiological aging, performances in vocabulary use are stable whereas those for long term memory, processing speed, and working memory decline slowly, but normal aging is not associated with global decline [28]. Nevertheless, cognitive 
performance declines differently depending on the individual; some individuals will present with preserved capacities while others will present with a marked decline. These differences may be explained by the notion of cognitive reserve, this being secondary to cultural levels, social environment, socio-professional activities and leisure activities which develop cerebral plasticity and alternative neural networks which then delay the manifestation of decline related to age and disorders [29]. The decline related to age is much slower and less clinically significant than the pre-dementia decline of AD. Some patients may show a mild deficit of one or more cognitive domains (mild cognitive impairment) [30]; it can cast doubt but often only the evolution makes it possible to confirm it is a pathological decline. The facts reported above from 1934 to 1940, taken individually could be considered as non-pathological and eventually secondary to cognitive decline related to age, but their repetition is equally more questionable as it falls within a cognitive deterioration which is slowly aggravated over the years.

$\mathrm{AD}$, after an imposing series of 1,110 autopsies conducted on subjects of 70 years of age or more, presenting a Mini-Mental Score inferior to 20 , is responsible for $82.9 \%$ of dementia syndromes (42.9\%, "pure" AD, 39.9\% AD associated with other pathologies) [31]. The prevalence of dementia syndromes augments considerably with age; a European collaborative study gives the following rates: $11 \%$ for men between the ages of 80 and $84,12.8 \%$ for the ages of 85 to 89 , and $22.1 \%$ for those over 90 years of age, and that for $\mathrm{AD}$ is $6.3,8.8$, and $17.7 \%$, respectively. For women, the prevalence of dementia syndromes is higher, respectively $12.6,20.2$, and 30.8 , and for $\mathrm{AD}$ 8.4, 14.2, and 23.6 [32].

In the case of Pétain, symptoms evolved progressively and inevitably. In June 1940, he met hitches with learning, judgment and mental flexibility, attention and memory dysfunction, apathy, and prosopagnosia; his personality was altered, and he became highly impressionable.

In 1942, the disorders were getting worse, with additional spells of confusion and disorientation. Theoretically neurocognitive disorders must be confirmed through a neuropsychological evaluation, which at this period of time was not possible. Furthermore, historians did not seek to know whether he was dependent for his activities of daily living. A posteriori it is therefore difficult to conclude on the severity of this evolutionary neurocognitive syndrome, the first evidences of which appeared in the 1930s. At most we can say that Pétain is in a phase of mental decline before and during the war.

From his trial in 1945, he presented the same signs as beforehand; he was more often disoriented, confused, and dependent for toileting and feeding. The criteria for dementia (DSM 4) and major neurocognitive syndrome (DSM 5) were present.

The only medical documents actually available are those from the doctors on the island of Yeu [13]. Bernard Ménétrel, his doctor, who was a personal friend, had probably hidden the disorders to maintain appearances and preserve his dignity. Unfortunately, he died accidentally in 1947 and his archives are considered lost [7]. It is thus impossible to give a diagnosis with some certitude as we do not hold his biological evaluations at our disposal, nor any complementary examinations, in particular the analysis of cerebrospinal fluid, cerebral imagery, neuropsychological evaluations, or anatomopathological examinations. At most, we know that he was not diabetic or hypertensive and that the arm swing and his stride stayed normal until 1949, that he did not have deficiency syndrome, tremors, difficulties with accommodation, or megalomaniac delusions [6, 9]. There were not any clinical arguments in favor of vascular injury or neurosyphilis.

Many witnesses signaled that, in 1940, he had moments of great intellectual alertness, alternating with episodes of apathy, and thus had a certain intellectual variability; it is possible that this was due to the administration of tonics (perhaps ephedrine or benzedrine) by his doctor $[5,7,33]$. Boller et al. reported that Pétain had a stiff gait in Vichy times [34], but later his prison guard Joseph Simon, gave a contradictory statement and reported that in 1945 he still walked very fast [35]. So as later he did not present with hallucinations or with Parkinson's disease, the diagnosis of Lewy body dementia seems very unlikely. The slowness of the smooth evolution of this disease which starts in an aged subject through memory troubles is thus strongly suggestive of $\mathrm{AD}$ beginning in the 1930s. In this disease, changes in executive functions can be precocious [36], which explains the importance of his impaired judgment as early as 1937. Due to a lack of anatomopathological examinations, the hypothesis of $\mathrm{AD}$, pure or eventually associated with other lesions, notably vascular, seems quite probably but cannot be confirmed given the state of current data.

In May 1940, Pétain was genuinely committed to fulfil a mission, but the task was too complex. The French army was defeated, 1.5 million men were 
prisoners in Germany, the German army occupied 2/3 of the country, and France had to bear the costs of the occupying forces while maintaining the unity of the French Empire (i.e., metropolitan France and its colonies). He failed to alleviate the hardships of occupation and to obtain the return of the imprisoned soldiers. It is probably for these reasons that he suggested collaboration with Hitler (Montoire, October 24, 1940) [8]. But at that time, he still did not realize the true nature of Hitler's National Socialism. He thought "Nazi Germany is simply a bellicose nation" [9]. In the meantime, he asked General Weygand to reorganize and rearm inconspicuously the French troops stationed in North Africa [13]. Later those troops will play an important role in the liberation of Corsica (September-October 1943), in the campaign of Italy (November 1943-July 1944) and in the liberation of the South of France in 1944. In November 1941, he did not oppose Weygand's return required by the Germans.

In 1940-1941, Pétain was very popular. Unaware of his cognitive deficiencies, the French people trusted him, and some engaged in collaboration [3]. Sadly, the deterioration of his cognitive functions no longer allowed him to play complex political games and he fell quickly under the influence of ministers and collaborators who wished the victory of Nazi Germany. When, in November 1942, the Germans invaded the South of France, the French fleet, stationed in the port of Toulon, did not sail to Algeria for lack of competent order and was scuttled for not being captured by the Germans [10]. From that date, he enjoyed being Head of the French State, but he no longer attended the Council of Ministers, just signed official documents, and delivered speeches written by his collaborators.

We must underline the responsibility of his entourage who kept tight secret about his pathology. His doctor should have advised him to withdraw. Maybe he did, but we have no record of it. Laval, Head of the Government, and the ministers should have done the same, but obviously they took advantage of his state of weakness and conducted a pro-German policy.

This presidential pathology should remind contemporary politicians that they can become ill just like anyone else, that their entourage can have interests in prolonging their term and to manipulate them. They should also meditate on the statement that Pétain declared in 1931, "it is better to leave things before they leave you" [8]. Unfortunately, without having applied this wise guideline, the name Pétain, after having enjoyed immense popularity, remains and will remain attached to numerous shameful acts.

\section{ACKNOWLEDGMENTS}

The authors thank Benedicte Vergez-Chaignon for her advices and Bernard Périsse for his linguistic help.

Authors' disclosures available online (https:// www.j-alz.com/manuscript-disclosures/19-0225r3).

\section{REFERENCES}

[1] Ballenger JF (2006) Self, Senility and Alzheimer's Disease in Modern America: A History. The Johns Hopkins University Press, Baltimore.

[2] Katzman R (1975) The prevalence and malignancy of Alzheimer disease. A major killer. Arch Neurol 33, 217-218.

[3] Amouroux H (1977) Quarante millions de Pétainistes. Robert Laffont, Paris, pp. 47.

[4] Tournoux JR (1980) Pétain et la France. Plon, Paris, pp. 29.

[5] Lottman HR (1984) Pétain. Editions du Seuil, Paris, pp. 243, 251, 289, 450, 455.

[6] Ferro M (1997) Pétain. Fayard, Paris, pp. 49, 144, 632, 635, 636.

[7] Vergez-Chaignon B (2001) Le Docteur Ménétrel. Perrin, Paris, pp. 83, 141, 166.

[8] Vergez-Chaignon B (2014) Pétain. Perrin, Paris, pp. 266, 316, 492, 514, 538, 707, 744-745, 831, 881-883, 884.

[9] Ferro M (2016) Pétain les leçons de l'histoire. Texto, Paris, pp. 76, 77-80, 191.

[10] Général Maurice Schmitt (1996) Le double jeu du Maréchal Pétain, légende ou réalité. Presse de la Cité, Paris, pp. 333.

[11] Jennekens FGI (2015) The cognitive decline of Marshal Philippe Pétain. Europ Neurol 74, 8-10.

[12] Bedel G (2014) Pétain Qui suis-je? Pardès, Grez-sur-Loing.

[13] Massonie A (2017) J'ai soigné Pétain. Tallandier, Paris, pp. 142.

[14] Schiavon Max (2018) Weygand L'intransigeant. Tallandier, Paris, pp. 207.

[15] Aron R (1954) Histoire de Vichy. Fayard, Paris, pp. 35, 36, $59,60$.

[16] Général Chauvineau (1938) Une invasion est-elle encore possible? Berger-Levrault, Nancy.

[17] Bardoux J (1957) Journal d'un témoin de la Troisième, 1 septembre 1939-15 juillet 1940. Fayard, Paris, pp. 330

[18] Reynaud P (1951) Au cœur de la mêlée. Flammarion, Paris, pp. 704-705.

[19] Destremau B (1990) Weygand. Perrin, Paris, pp. 731.

[20] Les Événements survenus en France de 1933 à 1944. Témoignages et documents recueillis par la commission d'enquête parlementaire. Séance du 17 février 1949: Audition de Marcel Héraud. PUF, Paris, t. 6

[21] Noguères L (1955) Le véritable procès du Maréchal Pétain. Fayard, Paris, pp. 59.

[22] Chastenet J (1970) Pétain de Pétain à de Gaulle. Fayard, Paris, pp. 63.

[23] Villiers G (1978) Témoignages. France-Empire, Paris, pp. 55-60.

[24] Général Serrigny (1959) Trente ans avec Pétain. Plon, Paris, pp. 230. 
[25] Bourget P (1960) Témoignages inédits sur le Maréchal Pétain. Fayard, Paris, pp. 172, 175.

[26] Tharaud J, Weygand M, Tracou J, Bailly A, de ChasseLoup-Laubat F (1951) Album du Maréchal Pétain. André Bonne, Paris.

[27] Bourget P (1966) Un certain Philippe Pétain. Casterman, Paris, pp. 167, 285, 288.

[28] Drag L, Bieliauskas LA (2010) Contemporary review 2009: Cognitive aging. J Ger Psych Neurol 23, 75-93.

[29] Jellinger K, Attems J (2013) Neuropathological approaches to cerebral aging and neuroplasticity. Dialogues Clin $\mathrm{Neu}$ rosci $15,29-43$.

[30] Petersen RC (2004) Mild cognitive impairment as a diagnostic entity. J Intern Med 256, 183-194.

[31] Jellinger KA, Attems J (2010) Prevalence of dementia disorders in the oldest-old: An autopsy study. Acta Neuropathol 119, 421-433.

[32] Lobo A, Launer LJ, Fratiglioni L, Andersen K, Di Carlo A, Breteler MM, Copeland JR, Dartigues JF, Jagger C, Martinez-Lage J, Soininen H, Hofman A (2000) Prevalence of dementia and major subtypes in Europe: A collaborative study of population- based cohorts. Neurologic Diseases in the Elderly Research Group. Neurology 54(11 Suppl 5), S4-9.

[33] Paxton RO (1973) La France de Vichy 1940-1944. Editions du Seuil, Paris, pp. 45.

[34] Boller F, Ganansia-Ganem, Lebert F, Pasquier F (1999) Neuropsychiatric afflictions of modern French Presidents: Maréchal Henri-Philippe Pétain and Paul Deschanel. Euro J Neurol 6, 133-136.

[35] Simon Joseph (1978) Pétain mon prisonnier. Plon, Paris, pp. 34.

[36] Carlson MC, Xue QL, Zhou J, Fried LP (2009) Executive decline and dysfunction precedes declines in memory: The Women's Health and Aging Study II. J Gerontol A Biol Sci Med Sci 64A, 110-117. 